\title{
ゲノム医療に係わる薬剤師の育成に向けた取り組み
}

\author{
櫻 井 洋 臣
}

\section{Efforts toward the Development of Pharmacist Involvement in Genomic Medicine}

\author{
Hiroomi Sakurai \\ Department of Hospital Pharmacy, Keio University Hospital; 35 Shinanomachi, Shinjuku-ku, Tokyo 160-8582, Japan.
}

(Received August 28, 2019)

\begin{abstract}
Since September of 2017, the Department of Pharmacy at Keio University Hospital has participated in activities of the A-3 Group in the "Program for Promoting a Platform of Genomics-based Drug Discovery" conducted by the Japan Agency for Medical Research and Development (AMED). The A-3 Group works to develop programs for fostering human resources in genomic medicine in order to solve various problems, and the Keio Department of Pharmacy plans and holds twice-yearly seminars for pharmacists interested in genomic medicine. In this review, we give an overview of efforts toward the development of pharmacists involved in genomic medicine, and we present the results of questionnaires about previous seminars.
\end{abstract}

Key words_ _ human resource development; genomic medicine; pharmacist; expert panel

\section{1.はじめに}

慶應義塾大学病院（以下，当院）は，2018 年 2 月 16 日にがんゲノム医療中核拠点病院の指定を受 け，当院に勤務する薬剤師も診療や教育への係わり が課せられている. また，がん対策基本法に基づく がん医療の提供に関しては, がん対策推進基本計画 （第 3 期）より「がんのゲノム医療の実用化に必要 な医療従事者を育成」が追加され，チーム医療で活 躍できる薬剤師の育成が求められている.

当院薬剤部は, 腫瘍センターゲノム医療ユニット 長の西原広史特任教授よりがんゲノム医療への協力 要請を受け, 2017 年 9 月より「国立研究開発法人 日本医療研究開発機構ゲノム創薬基盤推進研究事業 ゲノム創薬研究の推進に係る問題解決に関する研究 (A 課題)」（以下， A-3 班）の活動に参加し，がん ゲノム医療を取り巻く臨床業務の現状やゲノムチー 厶医療における多職種連携の必要性について理解を 深めている．また， 2017 年 12 月より，当院で遺伝 子パネル検査実施後のエキスパートパネル（Keio

慶應義塾大学病院薬剤部（干160-8582 東京都新宿区信 濃町 35)

e-mail: hiroomi.sakurai@adst.keio.ac.jp

本総説は, 日本薬学会第 139 年会シンポジウム S49 で

発表した内容を中心に記述したものである.
Cancer Genomic Board）が定期的に開催されるよ うになり，薬剤師も構成メンバーの一員として議論 に参加するようになった。本稿では，これまでに開 催した研修会の成果を紹介しつつ，がんゲノム医療 に係わる薬剤師の育成される側, 育成する側の両視 点から学んだことについて概説する。

\section{2. がんゲノム医療に係わる薬剤師としての自己} 研鑽

当院で感染制御, 緩和医療やがん薬物療法等に代 表される専門性の高い資格認定を有する薬剤師は, 医療の質と安全性を担保するために不可欠なチーム 医療で要の役割を担っている。しかしながら，がん ゲノム医療として遺伝子情報を収集・解析し，それ を臨床現場で生かすことができる薬剤師は，西原特 任教授よりゲノム医療への協力要請を受けた 2017 年 9 月時点では皆無であった.このため, 薬学部と 薬剂部から 1 名ずつがん領域の専門性を有する薬剤 師が空口担当者となり, 毎週開催されるエキスパー トパネルに出席して自己研鑽に励むところから取り 組みを開始した.

エキスパートパネルには，がんゲノム医療専門医 師を中心として病理専門医, 臨床遺伝専門医, 認定 遺伝カウンセラー, 臨床検査技師, バイオインフォ マティクス専門家や看護師等の様々な職種が一同に 
集まり，遺伝子パネル検查を受けた患者のがん遺伝 子変異に関する検討や推奨治療の提案が行われてい る。薬剤師がエキスパートパネルに参加し始めた当 初は，議論の内容を十分に理解することができな かったため，まずはドライバー遺伝子のように発が んへの関与が知られており治療標的としての介入 (Action) が期待される「Actionable 変異」，その中 で実際に投薬可能な薬剤が存在する遺伝子変異 「Druggable 変異」, ゲノムのコピー数変化・多型 $\lceil$ copy number variations; CNVs」や遺伝学的検査に おいて現時点でその変異が病的かどうか区別のつか ない遺伝子「variant of unknown significance; VUS」 等の基本的な用語や概念の理解・習得から始めた. また，公益社団法人日本臨床腫瘍学会が，がんのゲ ノム医療に関する遺伝子関連検査，患者・家族への 伝え方, 多職種との連携，意思決定支援等について 必要な知識・態度・技術の習得を目指して 2018 年 3 月 24，25 日に開催された研修会「がんゲノム医 療コーディネーター研修会」に参加し, 基礎知識の 習得と合わせて個々の職種が果たすべき役割をあら ためて認識することとなった．現在，エキスパート パネルにおいて薬剤師は，遺伝子変異に対する治療 薬の選択が保険適用可否も含めて正しいかどうかを 確認する治療薬の選定支援や治療効果と副作用のバ ランスを考慮した最適な投与量を提案する治療薬の 投与計画量決定支援等の役割を担うようになりつつ ある。

\section{3. ゲノム医療に係わる薬剤師育成に向けた研修 会の企画 ·開催}

A-3 班では，がんゲノム医療の担い手となり得る 臨床検査技師，看護師や薬剤師の人材育成が活動目 的の 1 つとなっている，当院は，薬剤師の育成に向 けた研修会の開催を担当することとなったが，当初 はどのようなプログラムが参加者に求められている かも手探り状態であった。このため, 医療機関で日 常業務を行っている病院薬剤師全般を対象にまずは 興味を持ってもらえるよう，がん領域だけではなく 非がん領域も含めたゲノム医療に関する研修会「ゲ ノム医療薬剤師ミニレクチャー」を 2018 年 3 月 10 日に開催した。 ミニレクチャーのプログラムは，以 下の内容とした.

1. ゲノム医療の概要

2. ゲノム医療の流れと倫理的側面
3. ファーマコジェネティクスの基礎と実例

4. ゲノム医療における看護師，臨床検査技師の 役割

5. グループディスカッション -ゲノム医療に 対する薬剤師の役割一

グループディスカッションでは，がんゲノム医療 の治療現場に対する薬剤師の係わり方や知識の習得 方法等に関する活発な意見交換が行われ，参加者に とってゲノム医療に第 1 歩を踏み出す機会が提供で きたと考えられる，一方で，参加者からは，基本的 な知識の情報提供と合わせて，ゲノム医療に係わる 際の個人情報の取り扱いやエキスパートパネルの実 際について学びたいとの要望が多かつた.このため, 2018 年 9 月 23 日に開催した研修会「ゲノム医療薬 剤師研修会 in 京都」におけるプログラムは，以下 の内容とした.

1. プレテスト

2. ゲノム医療の全体像と国の施策 一薬剤師に もとめられるもの-

3. ゲノム医療の技術・方法論

4. ゲノム医療におけるバイオインフォマティク ス

5. 臨床遺伝と個人情報保護

6. ファーマコジェネティクスの基礎と実例

7. グループディスカッション 一ゲノム医療に 関する事例検討一

8. ポストテスト・アンケート回答

研修会では，参加者の学習効果を把握する目的で 10 点満点の共通問題を使用したプレテスト/ポスト テストを実施した。結果は，Fig. 1 に示したように 参加者 77 名のプレテスト平均点が 4.7 点に対し て，ポストテストでは 7.3 点と有意な上昇 $(p<$ 0.01）を認めており，がんゲノム医療に関して一定 の理解は得られたものと考えている. 研修会終了後 に行った「研修会全体の満足度」と「研修会全体の 難易度」に対するアンケートでは，満足度に関して は 9 割以上の参加者より「満足」，「大変満足」とい う評価を頂けた反面，難易度に関しては 7 割近い参 加者が「少し難しい」,「難しい」という評価であつ た (Fig. 2).

\section{4. おわりに}

「がんゲノム医療の領域で薬剤師がどのような役 割を担っていけるのか」という部分に対しては，遺 


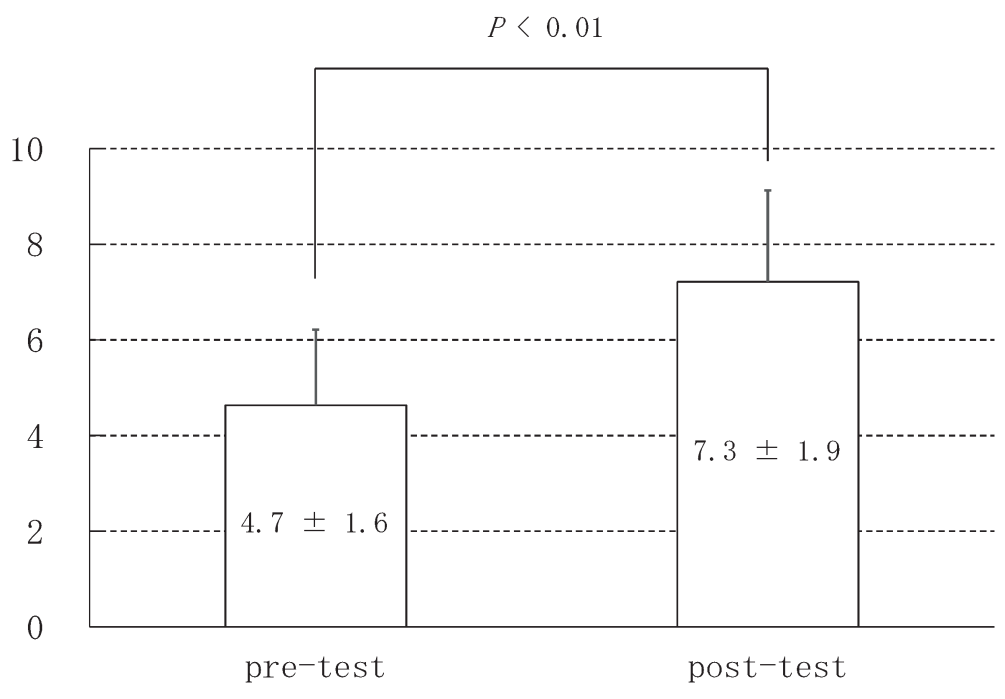

Fig. 1. Learning Effect Evaluated by Pre- and Post-test

\section{Satisfaction}

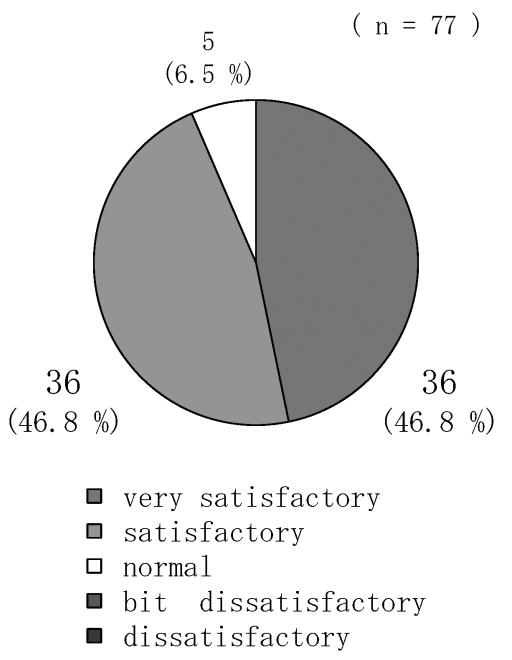

Difficulty $(\mathrm{n}=77)$

Fig. 2. Questionnaire Results on Satisfaction and Difficulty of the Workshop

伝子パネル検査が保険収載された 2019 年度よりが んゲノム医療中核拠点病院を中心に報告が増えてく ることが予想される。 A-3 班としての活動は, 2019 年度も年 2 回の研修会を開催する予定であり, 遺伝 子パネル検査に基づくがんゲノム医療を提供する中 で薬剤師が患者のあらゆるニーズに対して適切な対
応ができ, 患者が安心して治療を受けることができ るような臨床現場ですぐに応用可能な研修内容を提 供していきたいと考える.

利益相反＼cjkstart開示すべき利益相反はない. 